\title{
Repositioning Resistance: Basque Separatism, Religion and Cultural Security in Regional Queensland, 1945-1970
}

\section{Robert Mason}

robert.mason@usq.edu.au

On 26 April 1937, German bombers attacked the civilian population in the Basque market town of Guernica. The event has become synonymous with the brutality of the Spanish Civil War, but its impact on the Basque diaspora has not been the subject of detailed investigation. Large numbers of Basques emigrated to live in north Queensland, and the overwhelming majority can be traced to the hills surrounding Guernica. Those living in Australia only became aware of the atrocity over time, but the symbolic importance of Guernica increased over the subsequent decades as hundreds more Basques arrived in Queensland's north. The bombing itself was traumatic, but it was understood in the context of an emigration and historical injustice wrought by Spain's Nationalist dictatorship.

This article investigates the Basque population in north Queensland during the period from 1945 until the mid-1960s. It contributes to the growing debate on the effects of exposure to violence on Australian immigrants, but focuses on an experience of violence that endured beyond the specific event itself. The article uses oral history interviews and archival research to demonstrate the internal tensions within the various Spanish communities in northern Australia. It argues that Catholicism was one of a number of areas in which Basques sought to differentiate themselves from other Spaniards, and thereby accrue a sense of whiteness that was recognisably Northern European to the local Anglophone community.

\section{Australian Basques}

The three Basque provinces in Spain had long been the site of struggles for regional autonomy. ${ }^{1}$ Tensions had existed for centuries between the perceived imperialism of Castile and the peninsula's other regions, such as Catalonia and the Basque provinces. Claims for regional autonomy accelerated sharply following the loss of Spain's vestigial empire in 1898. Spanish politics polarised significantly during the early twentieth century, and would reach new heights when the Second Spanish Republic was declared in 1931 . The new republic was paralysed by divisive political debate, to which regional autonomy proved central. Matters reached an impasse in 
1936, when a conservative military coup precipitated the country's descent into a vicious civil war that lasted until 1939.

Basques constituted one of Spain's most numerous emigrant communities during the early twentieth century, and settled in countries throughout North and South America. ${ }^{2}$ Smaller numbers also arrived in Australia, initially settling in Sydney, before a significant proportion moved to the country's north in the years prior to World War I. ${ }^{3}$ In the interwar years, Basques established themselves as successful farmers in the sugar cane industry, and lived in coastal communities from Townsville to Mossman, north of Cairns. They were not the only Iberian group in Australia's north, but the Basques formed discrete communities that were geographically distinct from other Spanish-speaking populations. ${ }^{4}$ In the interwar period, almost 80 per cent of Ingham's Spanish population was Basque. In contrast, barely one in eight of Innisfail's diverse Spanish population was from the Basque provinces and half its members were Catalans.

The community of Basques rapidly established patterns of chain migration that focused on the Basque province of Gipuzcoa, from whence the overwhelming majority of Australian Basques originated prior to 1936. Circumstances in Spain had resulted in a sharp escalation in the numbers of Basque emigrants throughout the inter-war years, and the population in north Queensland numbered several hundred by the late 1930s. By the outbreak of the Spanish Civil War, almost all new arrivals to Queensland had travelled directly from their birthplaces in the hills to the east of Guernica (a region that formed the border between the Basque provinces of Bizkaia and Gipuzkoa). ${ }^{5}$

All emigration to Australia ceased with the outbreak of the Spanish Civil War. The Australian expatriate community became acutely concerned as the provinces soon became the front line in the conflict, before falling to the Nationalist forces in 1937. Still more troubling were the rumours of the bombing of Guernica that slowly reached Australia. The event was easily viewed from the hills and villages surrounding the town - a region from which almost all north Queensland's Basques had emigrated. The event could not be confirmed until the war's end, but rumours (and eventual proof that parents and friends had been killed) served to reinforce historical narratives of a rapacious Castilian Spanish imperialism among the Australian Basques. ${ }^{6}$

The decision to align with the Republican government proved fateful, and the victorious General Franco instigated decades of repression in reprisal. Franco's pursuit of autarky caused widespread food shortages throughout the provinces, and obliged Basques to rely on their hard-pressed smallholdings to support extended families. At the same time, Franco revoked the limited autonomy that Basques had previously enjoyed, and sought to excise Basque culture from public space. Spanish police from outside the provinces now garrisoned villages to monitor the inhabitants' daily life - actions that emigrants later recalled as symbolising the Nationalist government's status as an illegitimate occupier. ${ }^{7}$ Those who returned to the provinces after World War II were profoundly shocked by what they recalled as the 'tragic' destitution of the previously wealthy region, ${ }^{8}$ and many discretely sent gifts to family and friends affected by the war. ${ }^{9}$

Close family members in the provinces and Australia cooperated to facilitate emigrants' departure from 1946. In the immediate aftermath of World War II, many northern Basques sponsored dozens of would-be emigrants, with some successfully 
sponsoring over 100 compatriots. ${ }^{10}$ Australian immigration officials did not object, although they were a little bemused by the influx. Indeed, Basques were viewed as model settlers by the 1950s, and were characterised as both socially and politically conservative, pale-skinned, industrious Northern Europeans. Less clear to Australian officials were the changes that were occurring in the northern community, as the legacies of violence caused a re-evaluation of their Spanish heritage.

\section{Queensland's Spanish Connections}

Australians' characterisation of Basques reflected an unwillingness to consider the possible impact of prior violence on immigrants. A decade before David Cox's ground-breaking social outreach with Hungarian refugees in urban Melbourne, the government's emphasis remained on migrants' ability to work hard in order to make new lives that would contribute to national growth. The likely social and psychological impact of past injustice was not considered. Yet, as Jean Martin noted in 1953, a self-perceived status as 'political refugee' was one of the most enduring and formative influences that framed immigrants' engagement with Australian society. ${ }^{11}$

There has been an increased interest in Australian migrants' memories of violence, ${ }^{12}$ which builds on growing international engagement with questions of ethics and justice in the humanities. Few Australian historians have questioned the impact of reported social and political violence on groups of people who lacked a state of their own. ${ }^{13}$ This absence is noteworthy, since it is accompanied by a relative lack of historical research on the effect of ongoing violence in Australian immigrants' former homes. Ghassan Hage's work on transnational diasporic sentiment is instructive, and his analysis of migrant guilt can now be placed in an increasing body of research regarding migrant emotions. ${ }^{14}$ The Basque communities of north Queensland offer one potential case study through which to deepen scholarly understanding of this formative period in Australian immigration history.

Basque Australians drew on long-standing cultural memories in their response to Franco's attempts to fashion a unitary Spanish culture and his later desire to engage with expatriate Spanish migrants. While very few of them had been directly present in the town of Guernica during the bombing, the event became synonymous with the cultural trauma and loss they experienced. Horrified community discussion focused on the anonymous 'Spaniards' held to be responsible. These abstract symbols of imperial Spain signified the violence and unreconciled historical injustice wrought on the Basque people.

Franco formed a close alliance with the Catholic Church to formulate Spain's national reconciliation through conservative 'National Catholicism'. Strengthened ties of extra-territorial citizenship, through practical measures such as migrant congresses, were matched by calls for patriotism that focused on Spain's imperial past. While inveterate Republican exiles could be discounted as an 'anti-Spain', decades of austerity made the country's emigrants an appealing source of remittances. Yet, for north Queensland's Basque population, this 'National Catholicism' marginalised historical narratives other than Castilian imperialism and accentuated symbolic violence in emigrant communities.

Despite Basques' hostility, Franco was fortunate with regard to Australia's community of Spanish emigrants. Tangible connections between the two countries can 
be traced to the earliest European settlement of the continent. Attempts to establish the continent as a Benedictine province had led to the establishment of the Western Australian monastery at New Norcia, and this connection to Iberian Catholicism continued to flourish throughout the nineteenth and twentieth centuries. ${ }^{15}$ An informal infrastructure for contact existed on the basis of a long-established connection between the Australian and Spanish Catholic Church. An inter-war agreement had existed between the Augustinian order in Queensland and Manila, providing for a small number of Spanish clergy to reside in Queensland to improve their English before being posted to the Philippines. ${ }^{16}$ Some served as missionaries for Thursday Island's Filipino population at Keriri (also known as Hammond Island), ${ }^{17}$ but most were attached to St Monica's Cathedral in Cairns. ${ }^{18}$ Although the men did travel to outlying Spanish families in northern Australian townships, they were mainly focused on serving the Anglophone community. ${ }^{19}$

A large majority of these interwar men were Castilian, in common with most Spanish priests, and lacked cultural relevance for the ethnically diverse Spanishspeaking populations of north Queensland. Rather than provide a mnemonic bridge to former homes, for example, they reminded the many Catalan Australians of the rapacious Church-state alliance that had precipitated their initial emigration. ${ }^{20}$ Basques largely ignored the priests' ministrations as well, partly because they did not live close to the priests' base in Cairns, but also because of their desire to distance themselves from symbols of Spanish imperialism. In fairness, the interwar priests had been given a clear mandate to prepare for their Philippine posting, and were never intended to act as proxy chaplains to Australia's Spanish communities. They did represent one of a number of channels that connected the Australian and Spanish church.

Most of the clergy in the Basque provinces were ethnic Basques, and viewed local regional separatism and religious identity as inherently linked. ${ }^{21}$ The Basque church's strength lay in its long-standing integration into the fabric of local and individual identities. ${ }^{22}$ In contrast to many Basque priests, Spain's episcopal hierarchy aligned closely with Franco until the 1960s, and the dictator invested considerable effort in associating his government with conservative Catholic morality. Government attempts to increase the number of people speaking Castilian were articulated as exhortations for people to 'speak in Christian' rather than the regional languages. ${ }^{23}$

Anglo-Celtic Catholics in Australia felt a close affinity with the Spanish church during the Cold War, ${ }^{24}$ and the Australian church was at the forefront of attempts to conclude a formal migration agreement between Madrid and Canberra in 1957.25 Once the agreement was signed, the church remained engaged in the migration agreement, and acted as an agent to recruit female emigrants to Australia. ${ }^{26}$ Within Australia, priests lauded Franco's efforts to instil a sense of pride and conservative religiosity in Spain's emigrant communities. Although Australian bishops were generally reticent regarding the provision of migrant chaplains, the Spanish government's decision to provide a chaplain to Queensland was viewed with unusual equanimity. ${ }^{27}$

A number of Spanish clergy passed through Australia in the 1940s and 1950s, without the formal designation of 'migrant chaplains'. The overwhelming majority came to the country's north in the late 1950s, and were among large numbers of Spanish priests who volunteered for missionary duties throughout the world. ${ }^{28}$ 
Over half a dozen Augustinians served temporarily in north Queensland over several years, where they worked as missionaries in the rapidly expanding Spanish communities. ${ }^{29}$ The post-war Augustinians came to the state after their initial arrival in Manila, in contrast to the earlier practice of coming to Australia prior to their arrival in the Philippines. ${ }^{30}$ The emphasis remained on improving their English skills, but the clergymen also offered a cost-effective means to disseminate the reinvigorated style of 'National Catholicism' to Spanish emigrants.

The emphasis on the priests' English-language skills was clear. Most of the priests spent time in Brisbane's Villanova College to acclimatise before their journey to Australia's north were Spaniards, but those whose English proved ineffective were quickly reassigned to educational duties in the state's south-east. ${ }^{31}$ The Augustinian Father Luis Casado provides a particularly striking example. ${ }^{32} \mathrm{He}$ arrived in the Philippines after being expelled from communist China, and was subsequently posted to Queensland. He was initially sent to serve the northern Spanish community at Mareeba on the Atherton Tableland, but his English was poor and he was posted south to teach art at St James' College in Brisbane. His language skills did not improve, and he had a difficult relationship with his students. ${ }^{33}$ He was again transferred, this time to Saint Xavier's Home for Crippled Children. He was not alone at Saint Xavier's, as a Spanish nun, Remedio Gomez, similarly taught at the school. ${ }^{34}$ The schools were associated with a local parish where another Augustinian Spaniard served.

Despite the potential for contact, the northern Basque community remained wary of the priests. The men were predominantly Castilian - an ethnic group that constituted less than 10 per cent of Spaniards in north Queensland during the 1950s. The Spanish government insisted that emigrants remained an integral part of the nation, but priests struggled to embody a cultural unity that extended beyond a shared awareness of the Castilian language and vague affirmations of conservative Catholicism. ${ }^{35}$ In so doing, they recalled historical narratives of Castilian imperialism that were amplified by events during the Civil War and Franco's subsequent actions in the Basque provinces.

\section{Basque Australian identity and the Catholic Church}

Basques in Australia's north rejected the narratives of 'National Catholicism'. They sought other means to accrue local acceptance as a unique community of white immigrants. Religion had been a central tenet of Basque identity in the provinces, and remained so in Australia. Catholicism offered a key pathway for recognition as white Northern Europeans. They were aided in their attempt to accrue status as white immigrants since they arrived as sponsored immigrants rather than displaced persons. They were strongly aided in this by local Basque farmers, who (mis)characterised the Spanish immigrants to enthusiastic Australian farmers as being wholly Basque. ${ }^{36}$ It was anticipated that the first group of Spaniards to arrive in 1958, following the new intergovernmental migration agreement, would number 500 with an additional 350 cane-cutters planned for $1959 .{ }^{37}$ Significantly, and in the context of the White Australia policy, Canberra sought to restrict immigrants arriving as part of the agreement to northern Spaniards only. It was in this context that the first migrant chaplain was sent to Australia. 
Father Tomás Ormazabal's religious mandate and position were unclear from the time of his arrival. Although he initially expected to stay in Australia for only two years, he remained until his death in 1972. Ormazabal went directly to the northern town of Ingham, where he stayed for two years before moving south to base himself in Tully. ${ }^{38}$ All migrant chaplains in north Queensland struggled to serve their disparate congregations. Yet Ormazabal's difficulties were mitigated by the relatively affluent support network of established Basque farming families. In practice, much of Ormazabal's time was spent on long journeys to disparate Spanish-speaking communities from Dimbulah to Mackay, and west to Mt Isa.

Ormazabal's pastoral position was eased by virtue of his birth in Gipuzkoa. Financial insecurity placed strict parameters around his engagement with the wider Spanish community, and obliged him to focus his activities on predominantly Basque community events near his home. Even so, Basques were reluctant to provide funds to Ormazabal for the Catholic Church. Ormazabal's requests for funds from his ecclesiastical superiors were regularly rebuffed, and Basques recalled that he was advised 'to tell the people ... not to put pennies in the plate, but to put something that shines' ${ }^{39}$ He admitted that he 'hadn't got the courage to say that'. ${ }^{40}$ Ormazabal's expenses were largely funded through in-kind donations from within the Basque community. Despite an assertion that 'no discomfort could persuade him to a less demanding lifestyle', ${ }^{41}$ it was unlikely that Ormazabal had a choice, given that he relied on exhausting journeys to make contact with compatriots who could provide him with food and money. He routinely arrived at Basque houses at mealtimes, and learnt to park his car where friendly compatriots would discreetly fill it up with fuel while he occupied himself elsewhere. ${ }^{42}$

Spanish-speakers' contact with the migrant chaplain remained predominantly pragmatic and social, rather than religious. Basques were satisfied to have the opportunity for religious services performed by a Basque clergyman, and Ormazabal occasionally married Basque couples. Yet many established Basques preferred that Australian priests performed such sacraments, recognising the social capital accrued by the decision. Rather, Ormazabal's reception can be seen in the social context of Basque religiosity and collective identity, and he was most influential when re-enacting central features of Basque cultural and social memories. ${ }^{43}$

The local Anglophone clergy viewed the Basque chaplain with some suspicion. Many could not reconcile their understanding of the wealthy Spanish church with his complaints of impecuniosity, and were concerned that their own meagre parish revenues would be diverted to support the foreigner. His efforts to listen to Spanish radio exemplify his sense of isolation. One Anglophone priest recalled that:

he cut my best fishing line in two and used it to lift his wireless aerial up a tree so that he could get a good reception on his radio. He would be listening to these overseas places at 3 am and I know a young priest in Ingham who used to turn on an electric razor to create static when Father woke him at $3 \mathrm{am}^{44}$

His own difficulties aside, Ormazabal was deeply shocked by the local clergy's standard of living, and he felt Australian priests were an example of austerity compared with their Spanish counterparts. ${ }^{45}$

Ormazabal found himself at the centre of tensions within the ethnically and politically diverse Spanish communities. Basques felt that local Castilian and Andalusians' perceived aloofness towards the chaplain derived directly from his birthplace. 
Projecting a sense of historical injustice, Basques felt his situation reflected local Castilians' attempts to sustain a privileged position in Spain's ethnic hierarchy. ${ }^{46}$ Faced with navigating this microcosm of post-bellum Spain, Ormazabal offered local Spanish speakers assistance to find family members who had been displaced during the Civil War. ${ }^{47}$ While this was superficially apolitical, it distanced him significantly from Franco's regime and its traumatic policy of 'disappearing' its former adversaries. Ormazabal's actions aligned with those of the many local community members who sent funds to the Basque Government-in-Exile and refugee support groups. ${ }^{48}$ Although Ormazabal was careful that such activities did not compromise his position as a government-sponsored chaplain, his actions gave some moral recognition to Basques' sense of injustice, and assimilated their experiences within historical narratives of resistance to imperialism.

Local Basques' attitudes towards Ormazabal existed alongside his status as a migrant chaplain, who had been sent by the Spanish government and church to proselytise 'National Catholicism'. In line with the centrality of religious missions in 1950s Spain, Ormazabal chose missions as the format most likely to be successful and recognisable in his Australian context. ${ }^{49}$ Less than a year after his arrival, Ormazabal's first mission in Ayr was hailed as a marked success. Various Spanishspeaking community leaders attended the missionary events, and local Catholic media lauded the fact that almost every local Spaniard was present at the final mass. ${ }^{50}$ This seems unlikely, given Ayr's earlier history of radical anti-clericalism, and many attended from curiosity and childhood memories of local religious festivities. ${ }^{51}$ The commentary from the Anglophone Catholic press speaks more relevantly of Spain's privileged position in the Australian Catholic imagination than to a social reality among the emigrant community. ${ }^{52}$

The missions were one of the rare examples when Ormazabal conducted significant religious functions, and he continued to hold them during the 1960s. In the town of Ayr during 1966, for example, he arrived in the town one week prior to the mission in order to visit as many Spanish families as possible. The following week, Spaniards were encouraged to attend a daily mass in the town. A large mass and communion marked the culmination of the week. The mass and sermon were delivered in Castilian - although this is unremarkable given the local community was by then a thorough mix of Catalans, Basques, Andalusians and Castilians. Indeed, Basque Australian identity had developed significantly in the decades since the Civil War, embedding social memories of resistance and Guernica in regional Queensland.

Catholicism in rural Queensland resonated among the emigrant Basques, given their distance from urbanised centres of power. Traditional rural life in the Basque provinces remained threatened by Franco's cultural repression, as well as accelerating industrialisation. In this context, settlement in regional Queensland, with its large farms that could support extended family members, had genuine appeal for those Basques considering emigration. Although the migrant chaplain's presence in towns was often fleeting, Basque Australians recognised that he offered them social recognition among the wider community. Not only did his religious vows demand a degree of respect, but possessing a chaplain positioned the Basques as the equals of other national groups, such as the Italians and Maltese. The new chaplain proved central to Basques' ability to project a sense of respectability and to attain a degree of cultural affirmation. 
The memories and post-war experiences of established migrants differed radically from the historical narratives taught in Franco's Spain. The early migrants' sponsorship of their compatriots had been based on the perception that this would protect traditional Basque life, safeguarding memories of the oppression enacted by Franco. Totoricagüena Egurrola notes, with regard to the contemporary Basque Australian community, that, 'Those leaving after the Spanish Civil War would likely have specific and often traumatic foundations for their Basque identity and their homeland experiences. ${ }^{53}$ Although characterised by Totoricagüena Egurrola as 'political experiences', 54 a perception of loss and injustice through war raises fundamental questions about the degree of subjectivity that emigrant Basques recognised in their identity.

Older Basque settlers were confronted and troubled by later arrivals' more pragmatic relationship to Franco's government. ${ }^{55}$ For many Basque Australians, civil war and repression existed as traumatic memories, whose content was coloured by loss and guilt at their own escape from repression. ${ }^{56}$ Those who arrived after the immigration agreement of 1958 tended to judge the Spanish state as culpable of oppression, but censorship and cultural repression had silenced discussion of Guernica and the civil war. Notwithstanding these emerging differences, a sense of Basque difference remained in north Queensland. During one celebration in Ingham in the late 1950s, local Basques 'crucified' one of the new Spanish arrivals, who shouted 'Viva Franco!'; such individuals were ostracised from Basque community events. ${ }^{57}$

\section{Towards the 'Australian Way of Life'}

Religion offers the clearest example of Basques' reaction to other Spaniards and their sense of historical injustice. It was not the only instance, however, and a process of differentiation occurred in a variety of areas. Basques sought to preserve a sense of cultural security that was predicated on difference from other Spaniards. It was also based on a desire to distance themselves from local stereotypes of Southern Europeans. They were aided in this by the success and perceived industriousness of the Basque farming community, and by Ormazabal's presence. Their efforts to accrue whiteness can be seen in their enactment of social difference to the wider Anglo-Australian audience.

Queensland's northern Basques recognised the cultural capital afforded by their Catholicism. Basques drew deliberate attention to the historical parallels between the Irish and Basque people, pointing to a shared religious faith that was closely aligned with separatist sentiment and a supposed ethnic affinity as pale-skinned Celts. The presence of a distinctive religious identity was used in various social contexts. Ormazabal's legitimating presence helped to initiate a number of community social events that would grow and resonate with the wider local community over time.

Before the community established formalised Basque festivals, the Mendiolea farm in the northern township of Trebonne had provided a key social locale. Basque games, food and music were openly enjoyed in a family setting that recreated the traditional networks of extended family. Men would play the Basque drum and flute on weekends, while others performed the national dance with friends and family. This articulation of Basque identity in family spaces was not dissimilar to shifts 
that had occurred in the provinces themselves (albeit under pressure from a hostile government in Madrid). ${ }^{58}$ As importantly, the Mendiolea farm had reintroduced the family matriarch into what was otherwise a highly masculinised environment in north Queensland. Women acted as surrogate wives, mothers and sisters to the predominantly single men, who spent most of their time in distant barracks and all-male cane-cutting teams.

From the late 1950s, the large number of Basques in Queensland increased opportunities for recreation and more formal celebrations of a self-consciously Basque identity. Basques enacted similar practices at the many ethnic festivals throughout the global diaspora. Basque communities throughout the United States, for example, staged celebrations that focused on dance, public games and religious imagery. ${ }^{59}$ Such festivities provided important opportunities to speak Basque, but also reaffirmed cultural memories within the community. Simultaneously, the festivals projected Basque music, games and dance on to the local environment, embedding Basque migrant memories in the new locales.

Festivals in north Queensland proved particularly effective for a number of reasons. One was the presence of an authentic Basque priest, cast in opposition to National Catholicism and Castilian imperialism. This framed a tendency to enact those aspects of Basque culture that echoed Anglo-Australian identity and patterns of hegemonic whiteness. Over several years, the cultural spaces in which these identities were expressed gradually extended, as a more permanent Basque locale came to be centred on the township of Trebonne. This social milieu became closely connected to the production of food, the performance of music and playing sport.

The signing of the migration agreement in 1958 signalled a growing confidence among local Basque leaders. Encouraged by the local community's positive reaction towards the new arrivals, plans were made for an increasingly visible Basque social presence. The Jayo brothers and Alberto Urberuaga persuaded the owner of the local hotel to build a frontón, or traditional handball court, by taking him to the Mendiolea farm where improvised games were already played regularly. The publican agreed to build the court having noted the large crowd that had gathered to watch the fast-paced game, and the prodigious amount of alcohol that they consumed. ${ }^{60}$ The court was opened in November 1959 after having been blessed by Ormazabal. Soon after, local Basques constructed a wooden floor over nearby grass for large dances. The sense of a Basque cultural space was complemented when the Jayo family opened a bakery directly across the road and provided what quickly became locally renowned Basque food. Basque women took great pride in the churos machines they had brought from the provinces, and nearby Ingham became noted for its '[v]ery distinctive Basque environment' that approximated a 'Little Guernica' when the Basque women would meet to buy supplies. ${ }^{61}$

Australia's first St Ignacio Day Festival was organised in Ingham under the initial impetus of community stalwarts such as the Mendiolea and Badiola families. ${ }^{62}$ Basques travelled from throughout the surrounding districts to participate, and attendance at some events numbered almost 350 men, women and children from across the region. ${ }^{63}$ Local leaders from the wider community were invited, although those attending were largely Basque. ${ }^{64} \mathrm{With}$ few everyday opportunities to socialise in a Basque environment, St Ignacio Day provided a rare opportunity to recreate the social spaces and networks of Basque culture in regional Queensland. 
Ormazabal was central to the organisation and successful prosecution of Queensland's earliest Saint Ignacio Day festivals, and endorsed their social connotations for Basques despite Madrid's assertions that such festivities were subversive. ${ }^{65}$ He welcomed public opportunities to consolidate the particular expression of Catholic Basque identity, and used the festivals to preach to local and newly arrived Basques. ${ }^{66}$ The provinces' patron saint, St Ignacio Loyola, was barely known to Australia's Irish Catholics, who regarded the saint as a vague symbol of charity rather than of Basque ethnicity. Nonetheless, the recognisable connections between religion and ethnic difference helped validate Basque identity in the eyes of local Australian audiences who viewed the festivities.

While sport and music have long been central to Basque identity, Basque Australians quickly recognised that sport offered them particular opportunities to engage with the wider Anglophone society. Ormazabal encouraged migrants to keep up Basque sports as a healthy connection to their homeland, blessing Basque sports grounds to 'huge' crowds. ${ }^{67} \mathrm{He}$ proudly recalled that the first organised group of Basque emigrants to Australia had enthusiastically mimed a game of handball on the ship's deck, without either a ball or court markings. Enacting the unusual Basque sports also offered a means to capture the attention of the wider community, positioning Basques as masculine Northern Europeans compared with other migrant workers in the ethnically diverse sugar cane fields.

Sports' centrality to Basques' local identity had been emphasised on the opening of Trebonne's handball court, when an exhibition game was performed to a packed audience in traditional Basque clothes. Balanzategui notes that the headline annual competitions were reserved for Basques, although local non-Basques were permitted to play on other occasions. ${ }^{68}$ The court became the focal point for the Basque community, and weekend dances in the small township regularly attracted over 200 Basques. ${ }^{69}$ The appropriation of public space in Trebonne acted as a counterpoint to events in the Basque provinces, offering the emigrants a prominent community profile through which to challenge the actions of the Franco regime.

The Trebonne court also offered the Basque community tangible connections to the provinces. On his return from representing the Australian Spanish communities at a migrant congress in Spain in 1960, Urberuaga distributed the traditional handball bats and goatskin balls he had purchased for the local court while visiting the provinces. The local committee in charge of the court further developed the Basque connections afforded by the games, and regularly sent for replacement items from the provinces. Other sports were similarly organised to emphasise the emigrants' ongoing membership of a unique Basque diaspora, and to position the emigrants within the provinces' cultural landscape. Urberuaga later decided that a traditional stone weightlifting set would greatly benefit the northern community. He arranged for friends in the provinces to purchase and pay for the stones' shipment to Australia. He commented that the community 'could have used local stones for our sport, but it was important for us to get the genuine ones from the Pyrenees'. ${ }^{70}$ The Arrate family of Ayr overcame considerable bureaucratic confusion to import a further set of unwieldy txinga weights. The Vega family in the key donor village of Marquina in Vizcaya province also sent a set of stone weights to family members in Queensland (each stone weighing up to 300 kilograms). Their donation allowed Basques to organise public harrijasotzaile competitions from 1963 at the annual 
Maraka Festival, where they could demonstrate the traditional lifting, dragging and carrying of weights for Australian locals.

These weightlifting competitions not only created a sense of connectivity with the migrants' former homes, but captured the interest and imagination of Australian viewers. One journalist described the start of the weightlifting contest at the 1967 St Ignacio Day Festival, after the contestant had climbed into the back of the truck that served as a stage amid the large crowd. His description provides some insight into the passion and force associated with public displays of Basque identity in north Queensland:

The donning of the sash had an air of ritual. The hubbub died. Tension mounted. Three men were seated importantly on sandbags against the truck cabin: timekeeper, judge, and keeper of the official count. The crowd pressed right up against the sides of the truck. They were already loud with exhortation and advice.

Contestant and second faced each other. Between them stood a cylindrical block of stone about 2 feet high. It weighted (I learnt later) $225 \mathrm{lbs}$ [102 kgs]. It had twin handholes cut in the base.

The time-keeper signalled: 'go!' The crowd roared. The contestant stooped, straddled the block, knees bent, almost squatting, so that his stomach rested on top of the block.

He reached over and down, hands hooking naturally into the handholes. $\mathrm{He}$ heaved back, straining the block against his stomach and levering upwards ... [After the first successful lift, he dropped the weight from his shoulders] The big truck shuddered. The judge signalled a clean lift. Everybody counted out loud: 'one!'... Up she went again. Right this time! 'Thirteen!' The count went on. The din was terrific. In their passionate involvement, the spectators seemed to be trying by the sheer power of their vocal chords to help raise that cruel weight over those last agonizing inches onto the now-bleeding shoulder. ${ }^{71}$

In addition to the journalists, the local Irish doctor and parish priest were honoured guests. Although most participants in the competitions were Basque, the wider community was encouraged to view the sports and participate as the crowd. On at least one occasion, Anglophone locals were permitted to try to lift the weights as a demonstration of the tasks' arduous nature and the Basque men's skill and strength.

The reception of the sport and festivities were central to their purpose. The Basque emigrants consciously selected those sports connected to the Basque concept of indarra. This force of physical and spiritual endurance was usually projected across the Basque homeland, and was associated with channelling pain and masculine power. ${ }^{72}$ Sporting participants who displayed indarra embodied communal empowerment, but spectators also contributed to the force and used the sporting occasions as 'an external projection of indarra' ${ }^{73}$ The sporting display of masculinised prowess resonated with Anglophone Queenslanders, who already associated the Basques with Northern European values. The sports complemented Queenslanders' rugged culture of hegemonic masculinity and dominance over the environment. Basque identity was validated by the approving recognition it received from Anglophone locals, who praised the Basque 'migrant settlers, who are in many ways more Australian than the Australians' ${ }^{74}$ 
This comment is instructive of Basques' successful projection of difference to the wider community. Mark Lopez has characterised the 'Australian way of life' in this period as being 'the acceptance of distinctive Australian values of mateship, fair play, independence of spirit, self-reliance and a fair go for everyone'. ${ }^{75}$ In each of these areas, Basque sport, religion and culture thrived on social signifiers that created bridges to Anglo-Australians. Rather than critique the Basques' close ethnic bonds and community as representing a failure to assimilate and perpetuating a separatist political agenda, Basques were praised by locals for accepting 'Australian' habits.

\section{Conclusion}

The experience of Civil War and dictatorship wrought ongoing violence and cultural trauma on Spain's disparate emigrant communities. This article is based on a case study community of Basques, who predominantly had been born in the hills surrounding Guernica. The Australian community sought to differentiate themselves in a number of ways from the Spaniards, whom they judged culpable for the atrocity. The article does not suggest a profound antipathy between Spanish neighbours of different ethnic groups, but suggests a sense of injustice towards a stereotyped 'Spaniard'.

The presence of the Basque migrant chaplain, Tomás Ormazabal, brought many of these historical and contemporary tensions into focus. His presence recalled Basques' troubled identification with the Catholic Church, but offered a local point of focus for ethnic solidarity. Other aspects of the Basques' multi-layered response can be seen in their attitude to sport and public festivities. Their accrual of whiteness in the local community can be identified in their performance of masculinised sports and hegemonic whiteness. This differentiated the Basques from Spaniards (and other Southern Europeans), reinforcing a sense of difference in their European heritage and acceptance as white Australians.

\section{Endnotes}

1 While recognising the very significant population of Basques in France, this article focuses solely on the larger population in Spain. It is concerned with the three provinces currently administered as the Autonomous Community of the Basque Country, and excludes the Community of Navarre.

2 W. A. Douglass, Echalar and Murelaga: opportunity and rural exodus in two Spanish Basque villages (London: C. Hurst \& Co. 1975), p. 124.

3 W. A. Douglass, Azúcar Amargo: vida y fortuna de los Cortadores de Caña Italianos y Vascos en la Australia tropical (Bilbao: Servicio Editorial Universidad del País Vasco, 1996), p. 272; C. Poyotas Matas, 'The Basques', in M. Brändle (ed.), Multicultural Queensland 2001 (Brisbane: Queensland Government, 2001).

4 R. Mason, 'Agitators and patriots: cultural and political identity in Queensland's Spanish communities, 1900-1975', PhD thesis, University of Queensland (2009), pp. 98-9.

5 Mason, 'Agitators and patriots', p. 95.

6 B. V. Balanzategui, 'Basking in a different sun: the story of Conchi Mendiolea', in L. White and C. Watson (eds), Amatxi, amuna, amona: Writings in honor of Basque women (Reno, NV: University of Nevada Press, 2003), p. 39. 
7 'José', interview with author, 4 August 2007, Brisbane, Robert Mason Collection (hereafter RMC).

8 'Dolores', interview with author, 21 June 2007, Townville, RMC.

9 Gloria Totoricagüena Egurrola, Australia, Vasconia and the Lucky Country (Vitoria-Gasteiz, Servicio Central de Publicaciones del Gobierno Vasco, 2008), p. 88.

10 Balanzategui, 'Basking in a different sun', p. 34.

11 J. Martin, Refugee settlers: a study of refugee persons in Australia (Canberra: ANU Press 1966), p. 48.

12 J. Damousi, 'Legacies of war and migration: memories of war trauma, dislocation and second generation Greek-Australians', in N. Steiner, R. Mason and A. Hayes (eds), Migration and insecurity: citizenship and social inclusion in a transnational era (Oxford: Routledge, 2012), p. 32.

13 For an exception see, A. Gill, Interrupted journeys: young refugees from Hitler's Reich (Sydney: Simon and Schuster, 2004).

14 G. Hage, 'The differential intensities of social reality: migration, participation and guilt', in J. Frykman and N. Gilje (eds), Being there: new perspectives on the phenomenology and the analysis of culture (Lund: Nordic Academic Press, 2003), p. 90. On emotions, see S. Wills, 'Negotiating migration, sentiment, and insecurity: encounters with sadness and shame in Australia', in Steiner, Mason and Hayes, Migration and Insecurity, p. 64.

15 For further detail, see D. MacDermott, 'Rosendo Salvado and the Spanish contribution to Western Australia', in M. Jurak and E. Kardelj (eds), Australian papers: Yugoslavia, Europe and Australia (Ljubljana: University of Ljubljana, 1983), pp. 101-7; A. C. Staples, 'Spanish colonial influence on Sir James Stirling', Early Days: Journal of the Royal Western Australian Historical Society 10, 6 (1994), 593-604; C. Rodríguez, 'Oral history, autobiography and An intra-history of New Norcia', Oral History Association of Australia Journal 25 (2003), $31-6$.

16 A. Shnukal, 'They don't know what went on underneath: three little-known Filipino/Malay communities of Torres Strait', in A. Shnukal, G. Ramsay and Y. Nagata (eds), Navigating boundaries: the Asian diaspora in the Torres Strait (Canberra: Pandanus Books, 2004), p. 82.

17 BP4-3 Spanish De La Calle Hurtado C., Alien Registration Form, National Archives Collection, Brisbane (hereafter NAA B); BP4-3 Spanish de la Iglesia N, Alien Registration Form, NAA B.

18 S. Arneil, Out where the dead men lie: the Augustinians in Australia, 1838-1992 (Sydney: Augustinian Historical Commission, 1992), p. 365.

19 E. Vandeleur, correspondence with author detailing Innisfail Parish Records, 30 March 2007, Tully, RMC; BP9-3 Spanish Melecio P. R., Personal statement by Alien Passenger, NAA B.

20 R. Mason, “"No arms other than paper": Salvador Torrents and the formation of migrant identity in northern Australia, 1916-50', Australian Historical Studies 41, 2 (2010), 16680.

21 S. G. Payne, Basque nationalism (Reno, NV: University of Nevada Press, 1975), p. 90.

22 F. G. Cortazar and J. M. Azcona, El Nacionalismo Vasco (Madrid: Historia 16, 1991), p. 61.

23 K. Woolard, 'The problem of linguistic prestige: evidence from Catalonia', Penn Review of Linguistics 6 (1982), 28.

24 R. Mason, 'Spain, sectarianism and social memory in Cold War Queensland', JILAR Journal of Iberian and Latin American Research 13, 2 (2007), 9-28. 
25 Ignacio Garcia, Operación Canguro: the Spanish Migration Scheme, 1958-1963 (Canberra: Spanish Heritage Foundation, 2002).

26 C. Rico, 'A veteran of "Operation Marta", in C. Castelo (ed.), The Spanish experience in Australia (Canberra: Spanish Heritage Foundation, 2000), p. 77.

27 T. P. Boland, James Duhig (St Lucia: University of Queensland Press, 1986), p. 349.

28 For example, see BP25-1 Garcia Casimiro, Alien Registration Form, NAA B; for further detail, see J. A. Gallego, A. M. Pazos and L. Llera, Los Españoles entre la religión y la política: el Franquismo y la democracia (Madrid: Union Editoria, 1996), p. 64.

29 For example, see BP25-1 Casado D., Alien Registration Form, NAA B.

30 For example, see BP25-1 Fuertes A., Alien Registration Form, NAA B.

31 For example, see BP25-1 Pertejo J., Alien Registration Form, NAA B.

32 BP25-1 Casado L, Alien Registration Form, NAA B.

33 Arneil, Out where the dead men lie, p. 365.

34 BP289-1 1004179, Re-Entry Visa, NAA B.

35 'Nuestros emigrantes y los medios de difusión', July 1966, Emigrantes trasplante de Catolicismo, 1; 'Santiago y España', 12 July 1965, El Pilar, 1.

36 'Spanish Basque migrants regarded as outstanding', Herbert River Express, 29 November 1958, 1; 'Spanish Basque workers: sought for Ingham', Cairns Post, 15 August 1958, 9; 'Spanish migrants show greater interest in Australia', Herbert River Express, 25 February 1960, 1.

37 Mr Downer, 'Questions', 10 March 1959, Hansard, House of Representatives.

38 E. Vandeleur, Steps along the way: St Clare's Parish and School 75th Anniversary (Tully: St Clare's, 2003), p. 114.

39 'Dolores', 21 June 2007, RMC.

40 'Dolores', 21 June 2007, RMC.

41 Vandeleur, Steps along the way, p. 115.

42 Group interview number 4, interview with author, 29 November 2004, Mareeba, RMC; 'Emilio', interview with author, 27 November 2004, Cairns, RMC; 'Dolores', 21 June 2007, RMC.

43 Group interview number 4, 29 November 2004, RMC.

44 Father O'Connor, correspondence with author, Tully Heads, 20 January 2005, RMC.

45 Alberto Urberuaga, correspondence with Bianka Vidonja Balanzategui, 5 October 1999, Durango, Bianka Vidonja Balanzategui Personal Collection (hereafter BVBC). The author gratefully acknowledges the assistance provided by Ms Vidonja Balanzategui in making her research available.

46 Group interview number 4, 29 November 2004, RMC.

47 'Ramon', interview with author, 27 November 2004, Mossman, RMC.

48 Totoricagüena Egurrola, Australia, Vasconia and the Lucky Country, p. 252.

49 A. L. Orensanz, Religiosidad popular española, 1940-1965 (Madrid: Editora Nacional 1974), p. 23.

50 'Visit of Father Ormazabal', Townsville Catholic News, 1 February 1959, 15.

51 D. Menghetti, The red north: the popular front in North Queensland, Studies in North Queensland History, No. 3 (Townsville: History Department, James Cook University, 1981). For further discussion of local Spaniards, see Catalan footprint in Australia, accessed 18 December 2012, available from http://www.catalanfootprintinaustralia.net. 
52 Mason, 'Spain, sectarianism and social memory', 9-28.

53 Totoricagüena Egurrola, Australia, Vasconia and the Lucky Country, p. 29.

54 Totoricagüena Egurrola, Australia, Vasconia and the Lucky Country, p. 61.

55 J. A. Garcia, 'The Spanish Democratic Centre: a personal experience', in I. Garcia and A. Maraver (eds), Memories of Migration: seminar proceedings, University of Western Sydney Macarthur, 4 \& 5 September 1998 (Canberra: Spanish Heritage Foundation 1999), p. 157.

56 F. Mujcinovic, 'Multiple articulations of exile in US Latina literature: confronting exilic absence and trauma', MELUS 28, 4 (2003), 167-86; Hage, 'The differential intensities of social reality', 90.

57 'Stan', interview with author, 26 November 2004, Mena Creek, RMC.

58 A. Pérez-Agote, 'The role of religion in the definition of a symbolic conflict: religion and the Basque problem', Social Compass, 33 (1986), 428.

59 J. R. Smith, 'A different view of flight: understanding Basque women's immigration to the United States through oral history', Journal of the Society of Basque Studies in America 15 (1995): 40-55; G. P. Totoricagüena, 'Basques around the world: generic immigrants or diaspora?', Euskonews and Media 72 (2000): 24-31.

60 'Juan', interview with Bionka Vidonja Balanzategui, 30 May 1999, Ingham, BVBC.

61 Group interview number 4, 29 November 2004, RMC.

62 B. V. Balanzategui, 'The fronton: a Basque legacy in tropical north Queensland', Journal of the Society of Basque Studies in America 21 (2001): 17-28.

63 'Amaya', correspondence with Bionka Vidonja Balanzategui, 20 June 2001, Townsville, BVBC.

64 'Dolores', 21 June 2007, RMC.

65 Agustin Adarraga, correspondence with Bionka Vidonja Balanzategui, 10 June 1999, n. b., BVBC.

66 William Douglass, correspondence with Bionka Vidonja Balanzategui, 5 August 1996, Reno, BVBC.

67 'Trebonne has probably only Spanish handball court in Australia', Herbert River Express, 5 December 1959, 1.

68 Balanzategui, 'The fronton', 17-28.

69 'Felix', interview with Bionka Vidonja Balanzategui, 4 June 1999, Trebonne, BVBC.

70 'Spanish in North Queensland', Courier-Mail, 27 November 1980.

71 'The Basques: strongmen of the canefields', People, 18 October 1967, 13.

72 S. Ott, The circle of mountains: a Basque shepherding community (Oxford: Clarendon Press, 1981), p. 87.

73 T. Valle, Korrika: Basque ritual for ethnic identity, trans. L. White (Reno, NV: University of Nevada Press, 1994), p. 171.

74 'The Basques: strongmen of the canefields', 13.

75 M. Lopez, The origins of multiculturalism in Australian politics, 1945-1975 (Melbourne: Melbourne University Press, 2000), p. 48. 